NBER WORKING PAPER SERIES

\title{
CORPORATE GOVERNANCE, DEBT, AND INVESTMENT POLICY DURING THE GREAT DEPRESSION
}

\author{
John R. Graham \\ Sonali Hazarika \\ Krishnamoorthy Narasimhan \\ Working Paper 17387 \\ http://www.nber.org/papers/w17387 \\ NATIONAL BUREAU OF ECONOMIC RESEARCH \\ 1050 Massachusetts Avenue \\ Cambridge, MA 02138 \\ September 2011
}

We thank two anonymous referees, Murillo Campello, Campbell Harvey, David Hsieh, Pete Kyle, Ken Lehn, Anil Shivdasani, and seminar participants at Duke, Indiana, INSEAD, Rice, Virginia, and the Conference on Corporate Finance at Washington University in St. Louis for useful suggestions. James Kibler and Michael Albert provided excellent research assistance. Financial support from the Hartman Center is acknowledged. Hazarika gratefully acknowledges financial support from PSC-CUNY and the Baruch College Fund. The views expressed herein are those of the authors and do not necessarily reflect the views of the National Bureau of Economic Research.

NBER working papers are circulated for discussion and comment purposes. They have not been peerreviewed or been subject to the review by the NBER Board of Directors that accompanies official NBER publications.

(C) 2011 by John R. Graham, Sonali Hazarika, and Krishnamoorthy Narasimhan. All rights reserved. Short sections of text, not to exceed two paragraphs, may be quoted without explicit permission provided that full credit, including $(\odot)$ notice, is given to the source. 
Corporate Governance, Debt, and Investment Policy during the Great Depression

John R. Graham, Sonali Hazarika, and Krishnamoorthy Narasimhan

NBER Working Paper No. 17387

September 2011

JEL No. G31,G32,G34

\begin{abstract}
$\underline{\text { ABSTRACT }}$
We study a period of severe disequilibrium to investigate whether board characteristics are related to corporate investment, debt usage, and firm value. During the 1930-1938 Depression era, when the corporate sector was shocked by an unprecedented downturn, we document a relation between board characteristics and firm performance that varies in economically sensible ways: Complex firms (that would benefit more from board advice) exhibit a positive relation between board size and firm value, and simple firms exhibit a negative relation between board size and firm value. Moreover, simple firms with large boards do not downsize adequately in response to the severe economic contraction: they invest more (or shrink less) and use more debt during the 1930s. We document similar effects for the number of outside directors on the board. Finally, we also find that companies with properly aligned governance structures are more likely to replace the company president following poor performance.
\end{abstract}

John R. Graham

Duke University

Fuqua School of Business

100 Fuqua Drive

Durham, NC 27708-0120

and NBER

john.graham@duke.edu

Sonali Hazarika

Baruch College/CUNY

Zicklin School Of Business

One Bernard Baruch Way

55 Lexington Avenue at East 24th

New York, NY 10010

sonali.hazarika@baruch.cuny.edu
Krishnamoorthy Narasimhan

PIMCO

840 Newport Center Drive

Newport Beach, CA

Krishna.Narasimhan@pimco.com 


\section{Introduction}

A growing literature examines the interaction between corporate governance and firm performance. One hotly contested area investigates whether firm value is related to the characteristics of the board of directors. Some research argues that large boards are ineffective monitors of managerial performance and therefore reduce value (e.g., Jensen, 1993; Yermack, 1996; Eisenberg, Sundgren, and Wells, 1998). Similarly, boards with too many corporate insiders are thought by some to be ineffective and also reduce firm value (Lipton and Lorsch, 1992; Jensen, 1993). Other research argues that optimal board structure varies with the characteristics and needs of the firm (Lehn, Patro and Zhao, 2009; Boone, Field, Karpoff, and Raheja, 2007; Coles, Daniel, and Naveen, 2008, Hermalin and Weibach, 1998). These are important issues because of recent regulatory and institutional pressures that favor smaller or outsider-dominated boards.

Complicating the task of differentiating between these views, Demsetz and Lehn (1985) argue that in an equilibrium setting in which the explanatory variable(s) are jointly and endogenously chosen with the dependent variable, for example board attributes and firm value, one cannot ascribe causality to empirical relations between the variables of interest (see also Coles, Lemmon, and Meschke, 2011). This is not to say that firm value is unaffected by board characteristics, or that different types of firms do not benefit from different board arrangements. It may be possible to empirically detect whether board attributes are related to firm value and corporate decisions by observing companies that are not operating with optimal board structures due to, for example, transaction costs limiting board reorganizations (Coles et al., 2008). Such out-of-equilibrium occurrences could especially follow a large economic shock, coupled with transaction costs that hinder speedy corporate reorganization.

We study the Great Depression era to exploit before and after differences in the corporate sector, following a severe economic shock which was largely exogenous at the firm level. The Great Depression era was a turbulent time during which it is likely that board structures were thrown out of equilibrium (that is, pre-Depression board structures were not optimal after the inception of the Depression; board structures needed to change in response to the severe and unparalleled economic downturn). The 1920s were prosperous and exhibited strong growth, a period during which one could reasonably expect board size and independence to adapt to a firm's operating performance (or any suboptimal governance relations may have been masked by the overall positive economic environment). As such, in the 1920s we may not observe a relation between board attributes and firm performance, or even if we do, it would be difficult to assign causality (e.g., Demsetz and Lehn, 1985). In stark contrast, the deep 
contraction of the 1930s shocked the economy out of equilibrium. Assuming that there are transaction costs to reorganizing boards and that boards therefore re-equilibrate slowly, we expect that board attributes could affect corporate performance and decisions during the Depression. In particular, we argue that certain firms would benefit from having large boards with more independent directors, while the performance of other firms would suffer if they had boards with the same characteristics. Finally, after the Depression ended and firms over time adjusted towards optimal governance structures, we may again not find any relation between board characteristics and firm performance during 1939-1941 (after the Depression but before the US became involved in World War II), or even if we do, similar to the pre-Depression period, causality would be difficult to assign.

In terms of the role of boards, we focus on the interplay between board attributes and the complexity and scope of a firm's operations (Boone et al., 2007; Coles et al., 2008; Lehn et al., 2009). Typically, as companies increase their volume and scope of activity, they require a larger number of board members to provide advice on diverse issues. These complex firms might be expected to have more board members that provide specialized information and advice. In contrast, small, less complex firms do not have as pressing a need for specialized board advice and thus do not require as large a board (all else equal).

To consider these issues more explicitly, assume there are two kinds of firms: simple and complex, where we define the complexity of the contracting environment of the firm based on asset size and number of business segments. During the 1920s, assume governance structures are largely in equilibrium, that is, board structures have developed as an efficient response to the firm's operating environment. Firms of each type may have small random variations from optimal governance due to transactions costs, but no systematic non-random deviations should occur. The Depression shook the economy, increasing the importance of governance structure and the advice provided by the board.

Our hypothesis is that the value of the advice provided by the board of directors increased during the Depression. We conjecture that this is especially true for complex firms due to their large and complicated operations. For simple firms, board advice may well be valuable, but less so than it is for complex companies. Thus, based on the relative value of advice, holding all else constant, our hypothesis is that the net benefit of board size on firm valuation is larger for complex firms than for simple firms.

The previous discussion focuses on the relative valuation effects for complex firms compared to simple firms. What about the absolute valuation effect for complex and simple firms? As discussed next, there are several different forces at work, which makes it difficult to 
make an unambiguous prediction about whether the net effect of board characteristics on firm valuation is positive or negative during the Depression.

First, we argued above that the value of advice increased for all firms, which suggests that board size should grow for all firms. Second, however, an opposing force we refer to as the "downsizing effect" would work in the opposite direction, encouraging smaller boards (for any firm that shrank during the Depression). Given the severe economic downturn, firms may prudently reduce their asset size during the Depression. Given a smaller firm, board size might logically shrink as the firm downsizes, and if this moves the firm towards optimality, this could lead to a negative relation between board size and valuation. Consequently, it is difficult to make an explicit directional prediction on what would happen to board size, and associated valuation effects, during the Depression. Holding asset size fixed, the advice channel may encourage firms to have larger boards, or to increase board size, during the Depression, which may in turn increase value. However, the downsizing effect goes the other way, so we cannot make an unambiguous prediction. Ultimately, we let the data indicate which effect dominates. ${ }^{1}$

A third effect is also at work. While a firm may desire a larger board to receive more advice, there may also be costs to operating with a large board. For example, coordination costs may increase as board size grows. Even ignoring downsizing influences, it is not possible to make a definite prediction about the net benefits (advice benefit minus board costs) of operating with a larger board; that is, we cannot predict whether larger boards will be associated with positive or negative valuation effects. Instead, we allow the data to document for us whether the net effects are positive or negative. As mentioned above, due to greater advice value, all else equal we expect the valuation effects to be greater for complex than for simple firms.

If in the data we find a positive relation between board size and valuation among complex firms, and this positive effect is driven by complex firms that increased (or increased faster) their board sizes, this would be consistent with the advice effect dominating among these complex firms. That is, a positive relation would be consistent with the positive advice effect outweighing the negative valuation effects of board size due to downsizing or board costs, leaving the net impact positive. For similar reasons we could also find a positive relation between board size and firm value for simple firms during the Depression, though as mentioned above, all else equal we would expect the relation to be smaller for simple firms relative to the effect for complex firms. If however, we find a negative relation between board size and

\footnotetext{
${ }^{1}$ Rather than downsizing, it is possible that some firms increased asset size during the Depression, and therefore their boards might have grown along with firm size. Such board growth may have been to acquire more advice for the larger firm, among other possibilities.
} 
valuation among simple firms, and this negative effect is driven by simple firms that decreased (or decreased faster) their board sizes, this would be consistent with some combination of downsizing and board costs dominating the advice effect among simple firms.

We begin our analysis by studying the impact of boards on market valuation (as measured by Tobin's Q). Our sample consists of industrial CRSP firms during 1926 to 1941 , the period just preceding, during, and after the Great Depression. ${ }^{2}$ During the Depression (19301938), when the corporate sector was out of equilibrium, we find that among complex firms, board size is positively related to market valuation. Among simple firms, board size is negatively related to market valuation. Hence, our main prediction that board size valuation effects are more positive for complex firms is borne out in the data. Moreover, we find that changes in value are associated with changes in board size, for both types of firms. Among complex firms (which have greater advising needs and thus reap relatively greater benefits from a larger board), the benefits of having a large board appear to outweigh the effects of downsizing and board costs during the Great Depression. In simple firms, downsizing and the costs of a large board apparently outweigh the benefits because firm value is negatively correlated with board size. In the period before (1926-1929) and after (1939-41) the Depression we find no relation between board size and firm value.

Beyond documenting valuation effects, an important contribution of our paper is to study how board attributes may affect corporate value and activity. To our knowledge, this is the first paper that attempts to identify the specific corporate actions that are related to governancerelated valuation effects. In particular, we examine whether board attributes are correlated with corporate investment and financing decisions. Agency theory, beginning with Jensen and Meckling (1976), argues that managers do not always adopt investment policies or capital structures that maximize firm value. Under this view, managers may use company resources for personal gain, such as job security or empire building, at the cost of shareholder wealth. In the context of the Great Depression, self-interested managers might have sought to preserve their empires (by not sufficiently downsizing).

The severe negative shock of the Great Depression pushed the corporate sector out of equilibrium in the 1930s, and we study whether or not board characteristics are related to how firms operated in the Depression years. Interestingly, board size is positively correlated with corporate investment and debt usage in simple firms during the Depression, and changes in

\footnotetext{
${ }^{2}$ We refer to $1926-1929$ as the pre-Depression years and 1930-1938 as the Depression years. Gross National Product, employment and prices all declined sharply from late 1929. GNP did not reach 1928 levels again until 1938. We refer to $1939-1941$ as the post-Depression years.
} 
board characteristics drive these capital structure and investment changes. Moreover, investment and debt usage are negatively linked to changes in firm valuation for simple firms. This result that simple firms with large boards invest more and use more debt is consistent with an agency explanation of managers attempting to preserve their empires, even during the Depression, leading to reduced firm value. In the 1920s, and again in the post-Depression era, we do not find any systematic relation between board attributes and investment policy or debt usage in simple or complex firms. Thus, our results are not "hard-wired" to occur in all settings. Analogous to detecting an airplane's weaknesses during stress-tests, our governance findings are detectable only during the Depression. Supporting these conclusions, we also find that during the Depression, firms with properly aligned governance structures (e.g., smaller boards for simple firms) are more likely to replace the company President following poor performance.

Our valuation results complement the analysis of Coles et al. (2008), who argue that as circumstances change, optimal board attributes also change. Yet, because of transactions costs to adjusting board size and composition, at any point in time one could observe firms operating with suboptimal board arrangements. Coles et al. (2008) study ExecuComp firms in the decade starting in 1992 and empirically document a negative relation between firm value (measured by Tobin's Q) and board size for simple firms, and a positive relation in complex firms.

Our experimental design offers several advantages over that in Coles et al. (2008). First, while the theoretical governance arguments are based on observing firms operating out of equilibrium, Coles et al. (2008) examine 1992-2001 ExecuComp firms, a period of relative stability; thus, it is not clear how many firms were operating with sub-optimal governance structures during this period and therefore causality is difficult to assign. In contrast, we believe that our setting is a natural one to examine the effects of corporate governance because the severe exogenous shock of the Great Depression makes it plausible that many if not most firms were at least temporarily operating with sub-optimal governance structures. Second, we do a before, during and after analysis, and document board effects where we most expect to find them (in the 1930s, when the economy was exogenously shocked by the Great Depression) but no board effects during the 1920s or the post-Depression era. The variation in our before, during, and after results makes it less likely that the 1930's results are driven by some pervasive or unmodeled effect (more on this below).

Third, perhaps our most important contribution is that, in addition to documenting a relation between value and board characteristics, we also link these characteristics to real corporate decisions, namely, investment policy, capital structure, and executive turnover. This helps to explain how board attributes affect firm value. Fourth, we perform cross-sectional 
regressions to link the change in Tobin's $Q$, debt usage and investment to changes in board sizes (and number of outside directors). Fifth, by examining the 1920s and 1930s, we study corporate governance in a setting that is new to the literature. To the extent that our analysis confirms modern research, it serves to strengthen the received knowledge; however, to the extent that our results differ, it raises the possibility that what is accepted as received knowledge may need to be reevaluated.

Though we think it unlikely in our setting, it is possible that an unobserved variable could explain the relation between board attributes and firm value, debt policy, and corporate investment. For example, perhaps a bad CEO takes actions that reduce firm value and simultaneously appoints a large board full of his cronies. In this case, the unobserved "bad" managerial trait might drive both the dependent and explanatory variables, without one causing the other. We think that this is unlikely because of the number of things this unobserved variable would have to explain: 1) a relation between board attributes and firm outcomes in the 1930s that varies cross-sectionally in a way that is consistent with the advising theory of boards, 2) valuation results for the 1930s that are similar to those found in the 1990s, 3) the lack of a relation between board attributes and firm value in the 1920s and again in the post-Depression era, and 4) economically consistent results for debt, investment, and executive turnover policies in the 1930s. More specifically, this unobserved trait would need to explain the negative effect of a large board (with more outside directors) among simple firms in the 1930s, and the positive effect of a large board (with more outside directors) in complex firms in the 1930s, but no relation in these same firms in the 1920s or after the Depression ended, and the corroborating evidence from debt and investment policies for simple firms. While this might be possible, it seems to us to be very unlikely.

\section{Brief Literature Review}

\section{A. Corporate Governance}

Much research studies corporate governance in general, and board monitoring in particular. ${ }^{3}$ More than one perspective has emerged regarding optimal board size and selection of effective board members. Lipton and Lorsch (1992) and Jensen (1993) advocate smaller boards based on productivity considerations. They suggest that larger boards could be less effective than smaller boards because of coordination problems and director free-riding. Jensen

\footnotetext{
${ }^{3}$ See Shleifer and Vishny (1997) for a survey of the corporate governance literature. Denis (2001) reviews the field of corporate governance in the US. John and Senbet (1998) survey the empirical and theoretical literature on the mechanisms of corporate governance with a focus on internal governance. Hermalin and Weisbach (2003) survey board of director research.
} 
(1993) contends that when a board has more than seven or eight directors, the directors are less likely to function effectively and are easier for the CEO to control. He proposes the following as possible reasons for board failure: board size, lack of board member equity ownership, corporate insiders as board members, and a board culture that emphasizes politeness and courtesy at the expense of frankness and truth. Yermack (1996), Eisenberg, Sundgren, and Wells (1998) and Bhagat and Black (2002) show that firms with smaller boards have higher market valuations and higher operating profits.

Hermalin and Weisbach (1998), Raheja (2005), Adams and Ferreira (2007), and Harris and Raviv (2008) theoretically model the determinants of board structure, specifically the board's dual role of advising and monitoring management. Recent empirical papers in this area are described next. Linck, Netter and Yang (2008) find that firms structure their boards in response to the costs and benefits of the monitoring and advising functions. Coles et al. (2008) emphasize the advice provided by directors. ${ }^{4}$ They show that in firms with high-advising needs, larger boards (with more outside directors) are associated with higher Tobin's Q. In contrast, in firms needing less advice, smaller boards (with fewer outside directors) lead to higher market value. Lehn et al. (2009) find that board size is directly related to firm size and inversely related to proxies for growth opportunities, whereas the opposite patterns hold for insider representation. Boone et al. (2007) find that board size and independence increase as firms grow and diversify over time. Duchin, Matsusaka, and Ozbas (2010) show that the effectiveness of outside directors on firm performance depends on the cost of acquiring information about the firm: when information costs are high (low), outside directors reduce (improve) performance. ${ }^{5}$

\section{B. Great Depression}

The pre-Depression years were a period of progress and prosperity. The 'Roaring Twenties' saw significant technological advancement, investor confidence, and a record number of stock and bond issuances. In contrast, the Great Depression was a period of immense social and economic upheaval. Gross National Product, employment and prices all declined sharply after October 1929. The stock market plummeted from 1929 to 1933, with the market value of the NYSE declining from about $\$ 60$ billion in December 1928 to about $\$ 20$ billion in December 1932. The country's real GNP declined from about $\$ 191$ billion in 1928 to $\$ 141.5$ billion in 1933 .

\footnotetext{
${ }^{4}$ Other papers that consider the advisory role of boards include Klein (1998), Agrawal and Knoeber (2001), and Adams and Mehran (2003).

${ }^{5}$ There is debate about whether board structure affects firm value. Several studies prior to SarbanesOxley document no relation between the two (e.g., Bhagat and Black (2002)), while post- Sarbanes-Oxley studies such as Chhaochharia and Grinstein (2007), Bhagat and Bolton (2008), and Duchin, Matzusaka and Ozbas (2010) document a relation.
} 
Unemployment increased from $4.2 \%$ in 1928 to over $25 \%$ in 1933 . Following the trough there was an uneven recovery including another recession. GNP did not reach 1928 levels again until 1938. GNP grew rapidly over the next five years, increasing to about $\$ 280$ billion in 1942.

A growing literature emphasizes the role of financial factors in amplifying the shocks of the Great Depression on a given firm. Bernanke (1983) builds on the debt-deflation hypothesis of Fisher (1933) and explains that as the real value of nominal debt increased, firms with preexisting debt became increasingly credit-constrained and reduced investment. Calomiris and Mason (2003) show that leverage is an important determinant of bank distress during the Depression. Schiffman (2003) uses 1929-1940 firm-level data to explore the origins of financial distress and the investment behavior of distressed railroads. He finds that leverage negatively affected maintenance in smaller railroads. These papers suggest that high levels of debt hampered corporate performance during the Depression, implying that reducing debt would have been helpful. Using firm-level data of manufacturing firms in 1933-1938, Calomiris and Hubbard (1995) show that investment was sensitive to the availability of internal funds, among firms that faced a high premium to access external finance.

\section{Hypothesis Development}

We analyze the role of the board and assess how board attributes interact with corporate capital structure and investment decisions made during the Depression era. To do so, we first examine if and how board size impacts corporate valuation.

The Great Depression severely shocked the world economy in an unprecedented way. Thus, it is likely that firms needed to change their existing governance structures to respond to this unexpected crisis. Assuming nontrivial adjustment costs to changing the number or identity of directors, during the 1930s it seems likely that many firms operated with suboptimal board size and composition. In such a setting, it may be possible to document a relation between board attributes and corporate performance. The idea here is that while firms may have optimized (or close to it) governance structures in the 1920s, they were temporarily stuck with those structures in the 1930s when the Depression hit, due to board adjustments taking time because of transaction costs. In this period of disequilibrium, we may be able to document causal effects of board characteristics.

We analyze complex and simple firms separately. Consistent with the arguments in Boone et al. (2007), Coles et al. (2008) and Lehn et al. (2009) we conjecture that firms with more complex operations benefit from larger boards with more outside directors. Large multidivisional firms are likely to operate in multiple product and geographic markets, engage in 
more merger and acquisition activity, and use more sophisticated financing arrangements and marketing techniques. These companies are also likely to have more external contracting relationships and thus have greater advising needs, which can be provided by a larger board, and in particular by a larger number of outside directors (Pfeffer, 1972; Booth and Deli, 1996). In contrast, simple firms with less complex operations would require less specialized knowledge and hence would require a smaller board with fewer outside directors (all else equal).

We hypothesize that the value of advice increased during the Depression. The Depression being a period of severe and unprecedented economic distress, we conjecture that complex firms which have more complicated operations would benefit more from the advice provided by a larger board, compared to simple firms. Larger boards are on average made up of more outside experts who can provide such advice but this comes at a cost: coordination costs increase, leading to less nimble decision-making (Lipton and Lorsch, 1992 and Jensen, 1993).

We begin by analyzing the relation between corporate complexity and market valuation. Complex firms (i.e., large size or more than one business segment) generally have more involved contracting relations and therefore are expected to benefit from expert advice provided by directors during stressful economic times, more so than would simple firms. Thus we expect the net benefit of a large board to be more for complex firms than for simple firms.

In terms of whether the overall effect is negative or positive, we do not make a prediction but instead leave this to the empirical evidence. As discussed in the introduction, three effects are at work. The advice effect would lead to a positive relation between board size and valuation (which we hypothesize is greater for complex firms compared to simple firms). Secondly, there may be a downsizing effect that leads to a negative valuation relation with board size. This downsizing effect could occur because, due to the severe economic downturn, firms may reduce asset size and in turn board sizes during the Great Depression. Third, there can be disadvantages to operating with large boards (due to coordination/communication difficulties and slow decision-making which can be particularly damaging in a crisis). If these costs outweigh the benefits of large boards, we would find a negative relation between board size and valuation during the Depression. However, if we detect a positive relation between board size and valuation, and this effect is driven by firms that increased board size during the Depression, this would be consistent with the positive advice effect dominating the negative effects described above. We expect it to be more likely to detect this positive relation among complex firms. If, on the other hand, we detect a negative relation between board size and valuation, and this effect is driven by firms that decreased board size during the Depression, this would be 
consistent with downsizing and board costs dominating the advice effect during the Depression. Our hypotheses imply that it is more likely that we will detect this relation among simple firms.

It is difficult to predict ex ante how long firms might take to re-align their governance structures in the new economic reality. We study the Depression years of 1930-1938 in our tests. This is not to say that every firm would take exactly nine years to re-equilibrate governance. Rather, testing our hypotheses requires that enough firms are out of equilibrium during the 1930s so that averaged across all observations, we can detect empirical relations among the variables of interest.

A unique aspect of our study is that we also examine corporate investment and capital structure decisions in order to better understand how board attributes might affect decisionmaking, in turn influencing firm value. The Great Depression shocked the economy and aggregate demand fell sharply. The prudent corporate response may well have been to downsize. Agency theory suggests that managers attempt to look out for their own interests, even at the cost of shareholder wealth. With the onset of the Depression, the demand for most products declined dramatically. Under such circumstances, managers who were overseen by an efficient board would work in the shareholder's interest and reduce the scale of operations in an attempt to quickly reorganize the business. However, managers without appropriate board oversight might attempt to preserve their empires at all costs. These companies might downsize less and not reduce debt fast enough (or invest more and/or use more debt), even as the real cost increased substantially because of deflation, and the economy shrunk. Based on this agency argument, relative to well governed firms, poorly governed firms would increase investment and debt (or not reduce them as much) after the onset of the Depression.

As an additional test, we study one direct decision taken by the Board. We analyze the probability of a non-performing company President being replaced, and how the firm's governance structure impacts this decision. We expect that the probability of a non-performing President being fired would be higher in firms with properly aligned governance.

\section{Sample Selection and Variable Definitions}

\section{A. Sample}

Our sample consists of CRSP firms in 1928. Of the 657 companies on CRSP in 1928, we delete firms in heavily regulated industries: 34 utilities, 68 railroads, and 34 finance companies. This reduces the sample to 521 industrial firms.

We require that all sample firms be listed as of January 1928 and not delisted before December 1929. We impose this filter because firms that were delisted before December 1929 
were most likely distressed (or in some other way affected for reasons endogenous to the corporate attributes we study) prior to October 1929, and we want to focus on the effects of the unexpected, exogenous Depression shock. This filter reduces the sample size to 496 companies. The final requirement is that the firms have at least one year of accounting information prior to December 1928 so that we can examine performance both before and during the Depression. This results in a final sample of 446 industrial firms.

Each firm's accounting data are hand collected from the Moody's Investment Manual for Industrial Securities. The Moody's manual provides a brief description of the company and its divisions, the balance sheet, the profit and loss statement, lists of the firm's officers and directors, in addition to other corporate data. Information is collected from the manual for each sample firm for the years 1926-1941. The stock price data are obtained from CRSP.

\section{B. Variable Definitions}

Our goal is to study the relation between corporate governance and corporate policies. Our governance measures consist of three variables: board size, number of outside directors, and the percentage of outside directors. Board size is measured as the log of the total number of directors on a given firm's board. An outside director is defined as a board member who is not an officer of the firm. Thus, the percentage of outside directors is measured as the fraction of directors who are not officers. Data limitations do not allow us to identify grey directors ${ }^{6}$ (who we therefore group with outside directors). We do not perceive this to be a problem because grey directors are generally considered to be as likely as outsiders to give advice (see Coles et al. 2008), and our consideration of board effects is centered on the advising role.

We define companies with greater advising requirements in two ways: large firm size and diversification across different lines of business. ${ }^{7}$ Firm size is based on total assets and can change annually. Degree of diversification is a dummy variable equal to one for firms which operate in more than one business segment, based on our reading of the information provided in the Moody's manual at the beginning and the middle of the Depression years.

In our analyses, we include the explanatory variables used by Rajan and Zingales (1995) and numerous other studies, namely tangibility of assets, the market-to-book ratio, firm

\footnotetext{
${ }^{6}$ Grey directors are officers that have close business relationships with the firm but are not current employees. Former employees and individuals with family affiliations with the management are also considered to be grey directors.

${ }^{7}$ Coles et al. (2008) use these complexity definitions and also use leverage as an additional measure. We do not include leverage as a measure of firm complexity because it is one of our variables of interest. Also, if we regress board size on leverage and factors thought to affect board size, the leverage coefficient is insignificant, which is consistent with leverage not being a measure of complexity in our sample.
} 
size, and profitability. As detailed in the Appendix, we measure growth opportunities with the market-to-book ratio. Operating profit is earnings before interest and tax (EBIT) divided by the book value of total assets. We use EBIT because it is not directly affected by the level of indebtedness. Tangibility is the ratio of fixed assets to the book value of total assets. Firm size is defined as log of total assets. Volatility is measured as the volatility of a firm's stock price over the 12 months of the previous year. Liquidity is the ratio of cash to total assets. We conduct unreported robustness checks using the ratio of current assets to total assets as another liquidity measure, and all the results remain unchanged.

We examine three dependent variables: firm value (i.e., Tobin's Q), debt usage, and investment. Tobin's $Q$ is calculated as the sum of the book value of total liabilities and market capitalization of the firm, divided by the book value of its assets. Debt usage is measured as the ratio of the change in debt in the current year divided by the lagged book value of total assets. Investment during the year is calculated as the change in gross fixed assets from $\mathrm{t}-1$ to $\mathrm{t}$, divided by $\mathrm{t}-1$ total assets. Finally, the President change variable is coded as one if the President changed in a given firm-year and is zero otherwise.

Berger, Ofek, and Yermack (1997) point out that leverage at any instant in time provides only a snapshot of years of decisions about the firm's capital structure, and may not be the best measure to use to test the implications of agency theory. They argue that the study of change in debt levels, which isolates the present decisions about the firm's leverage policy, may be a better indicator of whether larger boards are less efficient, allowing greater managerial entrenchment and hence increased agency problems. ${ }^{8}$ Thus, in our tests we analyze the firm's debt usage decision as a function of board size and other firm characteristics.

\section{Empirical Analysis}

\section{A. Univariate Analysis}

Table I provides summary information about the pre-Depression (1926-29) and Depression (1930-38) samples. Panel A shows that, on average, debt use declined during the Depression. This is expected given that real debt became more expensive in the 1930s. We also find that Tobin's $Q$, operating profits and investment declined in the Depression, as expected.

In untabulated results, we find that the firms in the first seven deciles are fairly similar to each other, and small in terms of total assets, while the firms in the last three deciles are

\footnotetext{
${ }^{8}$ In a similar argument, MacKie-Mason (1990) states that debt-to-equity ratios represent the result of years of separate decisions and a study of these cumulative decisions is likely to have low power.
} 
notably larger. Therefore, in what follows, it seems reasonable to group firms into small versus large firm size at the $75^{\text {th }}$ percentile. The implications from our analysis are similar if we use all four quartiles to delineate firm size.

In our analysis we focus on the interaction between board size and two measures of complexity: firm size and diversification. To gauge complexity, we categorize small firms (in the first three size quartiles) as being less complex and having fewer advising needs during the Depression, relative to large firms. Large firms (in the largest size quartile) are more complex and have greater advising needs. Separately, we also measure complexity based on singlesegment (simple) versus multisegment (complex) firms. During the entire sample period (19261938) 24.9 percent of the firm-years represent large firms and 27.3 percent are multisegment. The percentages are quite similar for both the pre-Depression and Depression years.

Panel B of Table I compares board structures across the sample, conditional on size. We find that in both the pre-Depression and Depression years, board size increases with firm size (consistent with Boone et al. 2007). Further, there is a significant difference between the board sizes in the small and large firms. Similar to Coles et al. (2008), a fair portion of this difference is driven by the number of outside board directors. In untabulated analysis we compare the board structure of single-segment and multisegment firms, and find similar results.

It is interesting to note that the mean board size among simple firms shrunk significantly (at the 1 percent level) after the Depression shock. In contrast, the mean board size (though not the median) among complex firms grew during the Depression, though these changes are not significant at the 10 percent level. This pattern is consistent with simple firms (that have fewer advising needs) eventually shrinking their boards, and complex firms with greater advising needs maintaining or increasing board size during the Depression. Similarly, in the 1930s the mean number of outsiders decreased significantly for simple firms, while the mean number of outside directors increased for complex firms, though this change is not significant.

We also (untabulated) analyze Tobin's $Q$ in a $2 \times 2$ matrix of simple/complex firms versus small/large board size. The patterns indicate that firm value is higher among simple firms (both small and single-segment firms) that have small boards. In contrast, the pattern reverses among complex (large and multisegment) firms: $Q$ increases with board size among firms that have greater advising needs. These same patterns also hold for number of outside directors: Outsiders are valued more highly among complex firms (with greater advising needs). In the next section, we examine whether these results hold in a multivariate setting.

\section{B. Board Size and Market Valuation}


We begin the multivariate analysis by studying the relation between market valuation and board characteristics during the Depression years. In Table II we find that for the small firms (i.e., firms in the smallest three size quartiles) board size is negatively related to market valuation with an estimated coefficient of -0.127 in column (1). The coefficient on the board attribute*complex firm dummy (with complexity measured by either large size or multisegment) measures whether the effect of the board attribute is significantly different for complex firms compared to simple firms. In column (1) for firms in the largest quartile, board size is positively related to market valuation, with an estimated coefficient of 0.436 . Thus, the valuation impact of board size is significantly larger for complex firms, compared to simple firms.

To test whether board attributes are significantly different from zero for complex firms, we add the coefficients for the board variable and the board variable interacted with the complexity dummy. For example, in column (1) of Table II, the effect on valuation of board size for large firms equals $0.309(=-0.127+0.436)$, which has an unreported F-test $p$-value of 0.001 . The 0.309 coefficient is significantly positive, indicating that during the Depression, board size is positively related to complex firm market valuation. The estimated coefficients imply that for small firms with 11 members on the board, an increase of one member would decrease Tobin's $Q$ by 0.011 , which represents a decrease of 1.19 percent in the mean $Q$ of a small firm. For large firms with 11 members on the board, an increase of one member would increase Tobin's $Q$ by 0.027 , which represents an increase of 2.51 percent in mean $Q$. Similarly, firm value increases with board size for multisegment (complex) firms during the Depression era. These same patterns hold for number of outside directors. ${ }^{9}$

We perform firm fixed effects regressions, so our results are driven by time series variation in board size (or number of outside directors) within firms. Our results indicate that firms that changed their governance structures had higher valuations. An important aspect of the advice effect is that in complex firms, the positive relation between board size and Tobin's $Q$ is driven by firms that increased their board sizes. We test this directly in Table III, where we perform cross-sectional regressions with the change in Tobin's $Q$ for each firm over the period 1930-1938 as the dependent variable. These cross-sectional regressions contain one data point for each firm. The changes in Tobin's $Q$, growth options, operating profit, board size, and number of outside directors are calculated as the change from 1930 to 1938 . The other firm characteristics are at their median values over the Depression years (we get qualitatively similar results with the firm characteristics at their 1930 levels). We conduct separate analysis for

\footnotetext{
${ }^{9}$ In a robustness test, we add a lagged operating profit variable to the Table II regressions and the results are qualitatively similar.
} 
simple and complex firms. In the simple firm regressions, the explanatory variables include an indicator variable equal to one if board size (number of outside directors) decreases during the Depression period. In the complex firm regressions we include an indicator variable equal to one if the change in board size (number of outside directors) is positive over the Depression years. We find that the indicator variables are significantly positive in all the regressions, indicating that simple firms which decreased their board sizes, and complex firms which increased board sizes, experienced an increase in Tobin's $Q$.

The combination of firm fixed effect regressions and cross-sectional regressions help establish a link between changes in board size and changes in Tobin's Q. Our results show that complex firms benefit on net from director advice associated with larger boards, and firm value increases accordingly. Among simple firms, the downsizing impact and the negative effects (such as director free-riding or coordination costs) of large boards appear to dominate any benefits, leading to reduced firm value. Further analyses (not tabulated) indicate that simple firms which increased total assets and simple firms that decreased total assets reduce their board sizes. Given that the asset increase group would not be subject to the downsizing effect, the negative relation that we document implies that board costs were important for simple firms during the Depression years. ${ }^{10}$ Perhaps because enhanced coordination and communication amongst board members to take prompt decisions becomes especially important during a crisis.

\section{Debt Usage and Investment before and during the Depression}

We next examine whether board size and composition are related to corporate policies. We first analyze capital structure. Table IV presents Depression era analysis of debt usage during the current year regressed on firm characteristics from the end of the previous year. Two board complexity variables are included: board size and board size interacted with a complexity dummy variable.

Intriguingly, we find that board size is positively related to debt usage among small firms, with an estimated coefficient of 0.044 in column (1). Similarly, board size is positively related to debt usage among single-segment firms in column (3), with an estimated coefficient of 0.044. On average, during the Depression years, simple firms with large boards issued more debt (or retired loans more slowly) than simple firms with small boards; also, the effect for simple firms is larger than the effect for complex firms. These same implications hold with

\footnotetext{
${ }^{10}$ We perform regressions of log (board size) on log total assets and log assets squared (similar to Lehn, Patro and Zhao, 2009) for simple firms, and find that the coefficient on log assets is significantly positive, while the coefficient on log assets squared is significantly negative. This result is consistent with the argument that beyond a certain number of board members, the coordination costs and free-rider problems associated with additional board members dominate (Lehn, Patro and Zhao, 2009).
} 
respect to outside directors. Below (in Table VIII) we examine whether these capital structure choices are associated with reduced firm valuation in simple firms. Within the group of complex firms, board size has no relation with debt. To gauge economic significance, consider column (1) of Table IV. The estimated coefficients imply that for small firms with 11 members on the board, an increase of one member will increase debt (or reduce debt less) by 0.38 percent of total assets, or about $\$ 76,156$ annually.

We also non-parametrically investigate the interaction between debt policy, board size, and firm complexity. During the Depression (1930-1938), 32.42 percent of the firm-year observations increased debt (not tabulated). Among small firms that increased debt, 55.69 percent are in the largest board size quartile, compared to only 6.62 percent in the lowest board size quartile. ${ }^{11}$ Among the single-segment firms that increased debt, 54.23 percent were firms with board size in the largest quartile and only 7.03 percent were firms with board size in the lowest quartile. These findings again document that board size is positively associated with simple firm debt usage during the Depression.

In Table $\mathrm{V}$ we perform cross-sectional regressions of change in debt on firm characteristics during the Depression period. The changes in debt usage, growth options, operating profit, investment, board size and number of outside directors are calculated as the change from 1930 to 1938 . The other firm characteristics are at their median values over the Depression years (we get similar results if we use 1930 values). We conduct separate analyses for simple and complex firms. In the simple firm regressions, the explanatory variables include an indicator variable equal to one if the change in board size (number of outside directors) is negative over the Depression period. The complex firm regressions include an indicator variable equal to one if board size (number of outside directors) increases. We find that the indicator variables are significantly negative in the simple firm regressions, indicating that, on average, simple firms that decreased board sizes reduced debt usage. In the case of complex firms that increased their board sizes, the coefficient is negative though insignificant.

We also investigate whether this heightened use of debt by small firms with large boards might have been driven by liquidity needs. Perhaps these firms had to increase debt to cover existing interest payments, given the limited availability of other sources of funding. We investigate interest coverage (Perry and Shivdasani, 2005). Among the small firm-year observations that increased debt during the Depression, 95.41 percent had enough cash to cover the next year's interest expense. Thus, we do not find evidence that small-firm debt usage was driven by extreme short-term liquidity needs.

${ }^{11}$ For the small firms, the $75^{\text {th }}$ and $25^{\text {th }}$ percentile board sizes are 11 and 7 respectively. 
The results in Tables IV and V indicate that, on average, simple firms with large boards were more likely to increase debt during the Depression than simple firms with small boards (and also were more likely than complex firms). These results are consistent with managers of simple firms with large boards increasing debt, or decreasing debt less, perhaps in an effort to preserve an empire. To investigate this possibility further, we now study the link between investment and firm characteristics.

Table VI presents the investment analysis for the Depression era. We find that, on average, small and single-segment firms with larger boards invested relatively more during the 1930s (estimated coefficients of 0.075 and 0.084 , respectively, in columns (1) and (3)), controlling for other firm characteristics. This result also holds for similar specifications with log of outside directors as the board attribute. These results are consistent with the agency argument that firms with misaligned governance (i.e., simple firms with large boards) attempted to preserve their empires during the Depression, perhaps at the cost of shareholder wealth. Also note that we control for growth options in all our investment specifications (and in separate robustness tests, we also include Tobin's $Q$ as a right hand side variable), in an attempt to control for value-enhancing investment that some firms might conduct.

Column (1) of Table VI indicates that small firms with 11 members on their board completed mean (median) investment of about $\$ 129,812(\$ 102,647)$ less than a similar firm with 12 directors. The mean (median) value of fixed assets for the small firms in the 1930 s is $\$ 9.32$ million ( $\$ 6.12$ million) and hence, the incremental investment by a board of 12 members in comparison to a similar firm with 11 board members is 1.39 percent (1.68 percent) of the firm's fixed assets, annually. On average, during the Depression, this implies that simple firms with 12 members downsized by about 1.39 percent less each year than did their 11-member-board peers. This is a large relative effect during a period of sharply declining economic activity.

Non-parametric analysis shows that 50.64 percent of the firm-year observations have positive investment in the Depression (not tabulated). Among small firms that increased investment, 53.89 percent are in the largest board size quartile, compared to only 7.66 percent in the smallest board size quartile. Among the single-segment firms that increased investment, 52.22 percent had board size in the largest quartile and 7.94 percent had board size in the lowest quartile. This reinforces the point that simple firms with large boards continued to invest more during the Depression, in comparison to simple firms with small boards.

We further analyze the data to ascertain the governance structure of firms that decreased investment in the Depression years. In Table VII we perform cross-sectional regressions of change in investment on firm characteristics over the Depression period. Similar 
to Table V, the changes in the various variables are calculated as the change from 1930 to 1938 and the other firm characteristics are at their median values over the Depression years. We perform separate regressions for simple and complex firms. We find that the indicator variable for a decrease in board size (number of outside directors) is significantly negative in the simple firm regressions. Similarly, the indicator variable for an increase in board size (number of outside directors) is significantly negative in the complex firm regressions. This indicates that, on average, simple firms which decreased board sizes, and complex firms which increased their board sizes, reduced investment during the Depression era.

In summary, we find that, on average, simple firms with larger boards did not downsize during the Depression, relative to simple firms with smaller boards (and also relative to complex firms). This outcome is consistent with the idea that larger boards (with more outside directors) led to inefficient choices among simple firms, perhaps due to coordination issues or director free-riding (Lipton and Lorsch, 1992; Jensen, 1993), which is more conducive to empirebuilding. Such actions could lead to lower valuation during the Depression, consistent with the market valuation results of Table II in which simple firms with large boards had lower Tobin's $Q$. We investigate whether there is a direct link in the next section.

\section{Linking Corporate Policies to Firm Valuation}

In this section we attempt to directly link investment (and debt) policy to firm value, that is, to link the results in Table VI (and Table IV) to those in Table II. Our hypothesis is that firms that invest more (or shrink less) and use more debt (or retire debt slowly) during the Depression years are inefficient. This seems reasonable considering that this was a period of rapidly declining demand and increasing real cost of debt. In Table VIII we attempt to directly link Depression era debt usage and investment policy to changes in firm value during the Depression. This analysis uses change in Tobin's $Q$ as the left hand side variable. After controlling for factors such as liquidity, tangibility, etc., we find that corporate investment and debt usage are negatively related to changes in Tobin's $Q$ during the Depression. This evidence is consistent with investment and debt policies being two avenues by which corporate policies affect firm valuation, and thus connects our results in Table II with Table IV and Table VI.

\section{E. Intertemporal Changes in Board Structure}

The previous results are consistent with the exogenous shock of the Great Depression throwing firms out of equilibrium with respect to governance. If this is true, we should also observe firms with poor governance structures attempting to change their board structures. 
In untabulated analysis we find that intertemporal changes in the governance variables (board size and number of outside directors) increase in the Depression relative to the preDepression years. On average, in the pre-Depression years, board size and the number of outside directors remained relatively constant each year. In contrast, during the Depression, mean board size decreased by 0.06 per year and the mean number of outside directors decreased by 0.05 annually. Also, the standard deviation of the intertemporal changes in board size (number of outside directors) increased to 1.34 (1.34) in the Depression, compared to 1.10 (1.28) in the pre-Depression years. These results provide evidence that firms changed their governance structures as they attempted to survive the Depression. This increase in board activity is consistent with the corporate sector having been thrown out of equilibrium at the onset of the Depression, and then making changes to re-equilibrate.

Further, in the case of small firms (single-segment), compared to the pre-Depression years, during the Depression years there was a significant decrease of $0.30(0.33)$ in the average board size and of $0.19(0.21)$ in the mean number of outside directors. In the case of complex firms (multi-segment), the average board size increased by $0.24(0.13)$ and the mean number of outside directors increased by 0.07 (0.02) compared to the pre-Depression years, though these changes are not significant at the ten percent level. This shows that the shrinkage rate for boards was significant for simple firms; that is, simple firms downsized boards during the Depression in response to the negative economic environment, which is consistent with their boards being somewhat too large (too outside) following the onset of the Depression.

\section{F. Executive Turnover}

In the above analysis we examined corporate debt usage and investment decisions and linked them to the governance structure. Now, we study one direct decision taken by the board; the decision to fire a non-performing company President. We hand-collect data on Presidents for the firms in our sample for the pre-Depression and Depression years. As these data are from the 1920s and 1930s we cannot perform news searches to determine whether the President was forced out or left voluntarily (e.g., as in Huson, Parrino, and Starks, 2001). Thus, our analysis is on the entire sample of presidential turnover.

In untabulated tests we perform logistic regressions where the dependent variable is one when the President changed in a given firm-year, and zero otherwise. The independent variables are the one year lagged market-adjusted return, firm size, an interaction term and a stand-alone board size variable. For simple firms, the interaction variable is the product of the lagged market-adjusted return and a indicator variable equal to one if the board is in the lowest quartile of board size (or number of outside directors), and the stand-alone variable is a small 
board size indicator. For complex firms, the interaction term is the product of the lagged marketadjusted return and an indicator variable equal to one if the board is in the highest quartile of board size (or number of outside directors) and the stand-alone variable is a large board indicator. The coefficient on the lagged market-adjusted return variable is significantly negative in all models. The interaction term is negative in both specifications, though significant only for simple firms. This indicates that the probability of presidential turnover is significantly higher for poor performance in the case of simple firms with a smaller board size. For complex firms with a larger board size too, the probability of presidential turnover is higher for poor performance, though not significant at the ten percent level. This shows that the probability of the President being fired for poor performance increases in firms with governance structures more properly aligned to their advising needs in the Depression years.

While interesting in its own right, this result also lends credence to our earlier results on debt and investment policies which showed that firms with better governance structures decreased debt and investment during the Depression years, which increased firm value. Thus, it appears that firms with aligned boards took direct decisions (such as replacing a poorly performing President) and other decisions (specifically debt and investment policies) which were beneficial to the firm.

\section{G. Endogeneity and Robustness Tests}

The results so far document a relation between board size and firm value, investment policy, and debt usage during the 1930s. One advantage of our experiment is that the Great Depression can be considered exogenous to any given firm. This makes it harder to argue that reverse causality could drive our results, especially considering the differing results for simple versus complex firms conditional on board characteristics.

Nonetheless, we perform additional (untabulated) robustness checks to further mitigate concerns of reverse causality. (For example, perhaps simple firms increase board size after increasing debt, to boost monitoring.) First, we perform the regressions of Tobin's $Q$, debt usage and investment on data from the pre-Depression (1926-1929) and the post-Depression years (1939-41). We find no relation between board size or number of outside directors with Tobin's $Q$, debt usage or investment in either the period before or after the Depression ended. Thus, the only period during which we find a relation between board characteristics and corporate value and corporate policies is during the Depression era. These before, during, after findings make it seem less likely that our Depression results are hard-wired or driven by endogeneity or reverse causality. 
Secondly, we estimate a 3-stage least squares (3SLS) equation to address endogeneity concerns. This allows us to estimate debt usage (or investment) as a function of board size (or log of outside directors) and simultaneously estimate board size (or log of outside directors) as a function of debt usage (or investment). In the first stage, we predict board size (or log of outside directors) using as instruments the firm's age, the lag of the ratio of the firm's board size to the industry median board size (or ratio of firm's number of outside directors to the industry median number of outside directors), and the lagged percentage of outside directors. In the second stage we use predicted board size (or predicted log of outside directors) as a righthand variable in the debt usage (or investment) specification.

We find that board size is significant as a right-hand-side variable in the debt (or investment) specification. In contrast, in the first stage regressions, debt usage (or investment) is not significant as a right-hand-side variable in predicting board size (or log of outside directors). Thus, causality appears to run in one direction only, from board size to debt usage (or investment). Further, the results are similar to Tables IV and VI: board size is positively related to debt usage (or investment) among simple firms and not related for complex firms.

\section{Conclusions}

In this paper we assess the impact of board attributes on corporate valuation and decisions. We examine a sample of firms from 1926 to 1941, the years before, during, and after the Depression era. In addition to this period being historically very important, it is also interesting because it includes a period of prosperity, followed by a severe negative economic shock, followed by a return to relative stability. Moreover, the Depression can be viewed as an exogenous event at the firm level and hence provides an ideal setting to test our predictions in a 'before-and-after' comparison.

We find results that support the implications of agency theory. Board size is positively related to corporate investment in simple firms during the Depression. Moreover, we show that board size in simple firms has a strong positive association with debt usage in the Depression years. Overall, this is consistent with managers that work in companies with suboptimal boards pursuing their own objectives of 'empire preservation' at the cost of shareholder value.

Finally, we analyze executive turnover during the 1930s. Our results indicate that firms with properly aligned board structure (e.g., smaller boards for simple firms) were more likely to replace the company president following poor performance. 


\section{References}

Adams, R., Ferreira, D., 2007. A theory of friendly boards. Journal of Finance 62, 1, 217-250.

Adams, R., Mehran H., 2003. Board structure and banking firm performance. Federal Reserve Bank of New York Economic Policy Review 9, 123-142.

Agrawal, A., Knoeber, C., 2001. Do some outside directors play a political role? Journal of Law and Economics 14, 179-198.

Berger, P., Ofek, E., Yermack, D., 1997. Managerial entrenchment and capital structure decisions. Journal of Finance 52, 1411-1438.

Bernanke, B., 1983. Non-monetary effects of the financial crisis in the propagation of the Great Depression. American Economic Review 73, 3, 257-76.

Bhagat, S., Black, B., 2002. The non-correlation between board independence and long-term firm performance. Journal of Corporation Law 27, 2, 231-274.

Bhagat, S., Bolton, B., 2008. Corporate governance and firm performance. Journal of Corporate Finance 14, 257-273.

Boone, A., Field, L., Karpoff, M., Raheja, C., 2007. The determinants of corporate board size and composition: an empirical analysis. Journal of Financial Economics 85, 66-101.

Booth, J., Deli, D., 1996. Factors affecting the number of outside directorships held by CEOs. Journal of Financial Economics 40, 81-104.

Calomiris, C., Hubbard., R. Glenn, 1995. Internal finance and investment: evidence from the undistributed profits tax of 1936-37. Journal of Business 68, 4, 443-82.

Calomiris, C., Mason, R., 2003. Consequences of bank distress during the Great Depression. American Economic Review 93, 3, 937-947.

Chhaochharia, V., Grinstein Y., 2007. Corporate governance and firm value: the impact of the 2002 governance rules. Journal of Finance 62, 4, 1789-1825.

Coles, J., Lemmon, M., Meschke, J., 2011. Structural models and endogeneity in corporate finance: the link between managerial ownership and corporate performance. Journal of Financial Economics, forthcoming.

Coles, J., Daniel, N., Naveen, L., 2008. Boards: does one size fit all? Journal of Financial Economics 87, 329-356.

Demsetz, H., Lehn, K., 1985. The structure of corporate ownership: causes and consequences. The Journal of Political Economy 93, 6, 1155-1177.

Denis, D., 2001. Twenty-five years of corporate governance research ... and counting. Review of Financial Economics 10, 191-212.

Duchin, R., Matsusaka, J., Ozbas, O., 2010. When are outside directors effective? Journal of Financial Economics 96, 195-214

Eisenberg, T., Sundgren, S., Wells, M., 1998. Large board size and decreasing firm value in small firms. Journal of Financial Economics 48, 35-54.

Fisher, I., 1933. The debt-deflation theory of great depressions. Econometrica 1, 337-57. 
Harris, M., Raviv, A., 2008. A theory of board control and size. Review of Financial Studies 21, 1797-1832.

Hermalin, B., Weisbach, M. 1998. Endogenously chosen boards of directors and their monitoring of the CEO. American Economic Review 88, 96-118.

Hermalin, B., Weisbach, M., 2003. Boards of directors as an endogenously determined institution: a survey of the economic literature. Economic Policy Review 9, 7-26.

Huson, M.R., R. Parrino, L.T. Starks, 2001. Internal monitoring mechanisms and CEO turnover: A long-term perspective. Journal of Finance 56(6), 2265-2297.

Jensen, M., 1993. The modern industrial revolution, exit and the failure of internal control systems. Journal of Finance 48, 831-880.

Jensen, M., Meckling, W., 1976. Theorem of the firm: managerial behavior, agency cost and ownership structure. Journal of Financial Economics 3, 305-360.

John, K., Senbet, L., 1998. Corporate governance and board effectiveness. Journal of Banking and Finance 22, 371-403.

Klein, A., 1998. Firm performance and board committee structure. Journal of Law and Economics 41, 137-165.

Lehn, K., Patro, S., Zhao, M., 2009. Determinants of the size and structure of corporate boards: 1935-2000. Financial Management, 38, 4, 747-780.

Linck, J., Netter, J., Yang, T., 2008. A large sample study on board changes and determinants of board structure. Journal of Financial Economics, 87, 308-328.

Lipton, M., Lorsch, J., 1992. A modest proposal for improved corporate governance. Business Lawyer 48, 1, 59-77.

MacKie-Mason, J., 1990. Do taxes affect corporate financing decisions? Journal of Finance 45, 1471-1493.

Perry, T., Shivdasani, A., 2005. Do boards affect performance? Evidence from corporate restructuring. Journal of Business, 78, 4, 1403-1431.

Pfeffer, J., 1972. Size and composition of corporate boards of directors: the organization and its environment. Administrative Science Quarterly 17, 218-229.

Raheja, C. 2005. Determinants of board size and composition: A theory of corporate boards. Journal of Financial and Quantitative Analysis 40, 2, 283-306.

Rajan, R., Zingales, L., 1995. What do we know about capital structure? Some evidence from international data. Journal of Finance 50, 5, 1421-1460.

Schiffman, D., 2003. Shattered rails, ruined credit: financial fragility and railroad operations in the Great Depression. The Journal of Economic History 63, 3, 802-.825.

Shleifer, A., Vishny, R., 1997. A survey of corporate governance. Journal of Finance 52, 737783.

Yermack, D., 1996. Higher market valuation of companies with a small board of directors. Journal of Financial Economics 40, 185-221. 


\section{Appendix: Description of Variables}

\begin{tabular}{|c|c|}
\hline Variable & Definitions \\
\hline Tobin's Q & Total liabilities plus market capitalization of the firm, divided by total assets \\
\hline Growth Options & Market capitalization divided by book value of equity \\
\hline Operating Profit & Earnings before Interest and Taxes (EBIT) divided by total assets \\
\hline Volatility & $\begin{array}{l}\text { Standard deviation of the firm's stock price over the } 12 \text { months of the } \\
\text { previous year }\end{array}$ \\
\hline Leverage & Ratio of total debt to total assets \\
\hline Tangibility & Ratio of fixed assets to total assets \\
\hline Firm Size & Log of total assets \\
\hline Liquidity & Ratio of cash to total assets \\
\hline Investment & $\begin{array}{l}\text { Change in the dollar value of gross fixed assets from } \mathrm{t}-1 \text { to } \mathrm{t} \text {, divided by } \\
\text { total assets. }\end{array}$ \\
\hline Debt Usage & Change in the dollar value of total debt, divided by total assets \\
\hline LARGE Dummy & $\begin{array}{l}\text { Equal to one for firms in the top } 25 \text { percent of all firms based on total } \\
\text { assets in a given year }\end{array}$ \\
\hline MULTISEGMENT Dummy & Equal to one for firms operating in more than one business segment \\
\hline Board Size & Log of the total number of board members \\
\hline Ln(Outside Directors) & Log of total number of outside directors of the firm \\
\hline $\begin{array}{l}\text { Percentage of Outside } \\
\text { Directors }\end{array}$ & Percentage of directors who are not officers of the firm \\
\hline
\end{tabular}




\section{Table I}

\section{Summary Statistics}

Panel A presents descriptive statistics for our sample firms. The sample consists of 4,797 annual observations for 446 industrial companies between 1926 and 1938. The table reports the mean and median values of relevant variables for the pre-Depression (1926-29) and Depression years (1930-38). Two-sided p-values are reported in parentheses. Panel B compares board structures across small and large firms. The firms in the first 3 size quartiles based on total assets per year are grouped as small firms and the firms in the largest size quartile are the large firms. Two-sided p-values are reported in parentheses.

\begin{tabular}{|c|c|c|c|c|c|c|}
\hline \multicolumn{7}{|c|}{ Panel A } \\
\hline . & \multicolumn{2}{|c|}{ Pre-Depression Years } & \multicolumn{2}{|c|}{ Depression Years } & \multicolumn{2}{|c|}{ Differences } \\
\hline & Mean & Median & Mean & Median & Mean & Median \\
\hline Tobin's Q & 1.30 & 0.97 & 0.96 & 0.76 & $\begin{array}{l}-0.34^{* * *} \\
(0.00)\end{array}$ & $\begin{array}{l}-0.21^{* * *} \\
(0.00)\end{array}$ \\
\hline Operating Profit (\%) & 8.59 & 7.64 & 4.39 & 3.91 & $\begin{array}{l}-4.20^{* * *} \\
(0.00)\end{array}$ & $\begin{array}{l}-3.73^{\star * *} \\
(0.00)\end{array}$ \\
\hline $\begin{array}{l}\text { Book Value of Total } \\
\text { Assets ( } \$ \text { million) }\end{array}$ & 73.05 & 25.96 & 79.87 & 22.72 & $\begin{array}{l}6.82 \\
(0.23)\end{array}$ & $\begin{array}{l}-3.24^{\star * *} \\
(0.00)\end{array}$ \\
\hline Investment (\%) & 4.00 & 0.88 & -1.31 & -0.88 & $\begin{array}{l}-5.31^{* \star *} \\
(0.00)\end{array}$ & $\begin{array}{l}-1.76^{\star * *} \\
(0.00)\end{array}$ \\
\hline Debt Usage (\%) & 0.61 & 0.00 & -0.33 & 0.00 & $\begin{array}{l}-0.94^{* * *} \\
(0.01)\end{array}$ & $\begin{array}{l}0.00 \\
(0.14)\end{array}$ \\
\hline Board Size & 11.14 & 11.00 & 10.97 & 10.00 & $\begin{array}{l}-0.17 \\
(0.19)\end{array}$ & $\begin{array}{l}-1.00^{\star *} \\
(0.02)\end{array}$ \\
\hline No. of Outside Directors & 6.98 & 6.00 & 6.86 & 6.00 & $\begin{array}{l}-0.12 \\
(0.28)\end{array}$ & $\begin{array}{l}0.00^{*} \\
(0.05)\end{array}$ \\
\hline $\begin{array}{l}\text { Percentage of Outside } \\
\text { Directors }\end{array}$ & 60.43 & 63.64 & 59.87 & 62.50 & $\begin{array}{l}-0.56 \\
(0.31)\end{array}$ & $\begin{array}{l}-1.14 \\
(0.51)\end{array}$ \\
\hline
\end{tabular}

Panel B

\begin{tabular}{|c|c|c|c|c|c|c|}
\hline \multicolumn{7}{|c|}{ Pre-Depression years (1926-1929) } \\
\hline & \multicolumn{2}{|c|}{ Board Size } & \multicolumn{2}{|c|}{ Outside Directors } & \multicolumn{2}{|c|}{ Percentage of Outside Directors } \\
\hline & Mean & Median & Mean & Median & Mean & Median \\
\hline Small Firms & 10.16 & 9.00 & 6.27 & 6.00 & 59.46 & 61.54 \\
\hline Large Firms & 14.08 & 14.00 & 9.14 & 9.00 & 63.33 & 66.67 \\
\hline$p$-value of difference & $(0.00)$ & $(0.00)$ & $(0.00)$ & $(0.00)$ & $(0.01)$ & $(0.00)$ \\
\hline \multicolumn{7}{|c|}{ Depression years (1930-1938) } \\
\hline Small Firms & 9.86 & 9.00 & 6.07 & 6.00 & 59.12 & 60.00 \\
\hline Large Firms & 14.32 & 13.00 & 9.24 & 9.00 & 62.13 & 66.67 \\
\hline$p$-value of difference & $(0.00)$ & $(0.00)$ & $(0.00)$ & $(0.00)$ & $(0.00)$ & $(0.00)$ \\
\hline
\end{tabular}


Table II

Regression of Tobin's Q on Firm Characteristics for the Depression Years

This table presents the results of a firm fixed effects regression of market valuation on firm characteristics for the Depression years, 1930-1938. Columns (1) and (3) use board size as the governance variable, while columns (2) and (4) use In(outside directors). The regressions have an unreported intercept term. Two-sided $p$-values are reported in parentheses. ${ }^{* * *},{ }^{* *},{ }^{*}$ represent significance at 1,5 , and $10 \%$, respectively.

\begin{tabular}{|c|c|c|c|c|}
\hline Variable & (1) & (2) & (3) & (4) \\
\hline Operating Profit & $\begin{array}{l}2.056^{* * *} \\
(0.00)\end{array}$ & $\begin{array}{l}2.046^{* * *} \\
(0.00)\end{array}$ & $\begin{array}{l}2.030^{* * *} \\
(0.00)\end{array}$ & $\begin{array}{l}2.028^{* * *} \\
(0.00)\end{array}$ \\
\hline Volatility & $\begin{array}{l}0.011^{\star * *} \\
(0.00)\end{array}$ & $\begin{array}{l}0.011^{* * *} \\
(0.00)\end{array}$ & $\begin{array}{l}0.011^{* \star *} \\
(0.00)\end{array}$ & $\begin{array}{l}0.011^{\star \star *} \\
(0.00)\end{array}$ \\
\hline Leverage & $\begin{array}{l}0.251^{* *} \\
(0.04)\end{array}$ & $\begin{array}{l}0.262^{\star *} \\
(0.03)\end{array}$ & $\begin{array}{l}0.241^{* *} \\
(0.05)\end{array}$ & $\begin{array}{l}0.264^{\star *} \\
(0.03)\end{array}$ \\
\hline LARGE Dummy & $\begin{array}{l}-1.215^{\star * *} \\
(0.00)\end{array}$ & $\begin{array}{l}-0.655^{\star * *} \\
(0.00)\end{array}$ & & \\
\hline MULTISEGMENT Dummy & & & $\begin{array}{l}-1.107^{\star *} \\
(0.04)\end{array}$ & $\begin{array}{l}-0.362 \\
(0.42)\end{array}$ \\
\hline Tangibility & $\begin{array}{l}-0.305^{\star * *} \\
(0.00)\end{array}$ & $\begin{array}{l}-0.302^{* * *} \\
(0.00)\end{array}$ & $\begin{array}{l}-0.330^{* * *} \\
(0.00)\end{array}$ & $\begin{array}{l}-0.328^{* * *} \\
(0.00)\end{array}$ \\
\hline Liquidity & $\begin{array}{l}0.645^{\star * *} \\
(0.00)\end{array}$ & $\begin{array}{l}0.604^{* * *} \\
(0.00)\end{array}$ & $\begin{array}{l}0.647^{\star * *} \\
(0.00)\end{array}$ & $\begin{array}{l}0.628^{* * *} \\
(0.00)\end{array}$ \\
\hline Board Size & $\begin{array}{l}-0.127^{*} \\
(0.06)\end{array}$ & & $\begin{array}{l}-0.133^{*} \\
(0.07)\end{array}$ & \\
\hline Board Size * LARGE Dummy & $\begin{array}{l}0.436^{* \star \star} \\
(0.00)\end{array}$ & & & \\
\hline Board Size * MULTISEGMENT Dummy & & & $\begin{array}{l}0.345^{\star \star \star} \\
(0.01)\end{array}$ & \\
\hline Ln(Outsider Directors) & & $\begin{array}{l}-0.139^{\star \star} \\
(0.01)\end{array}$ & & $\begin{array}{l}-0.155^{\star * *} \\
(0.01)\end{array}$ \\
\hline Ln(Outsider Directors)* LARGE Dummy & & $\begin{array}{l}0.274^{\star \star \star} \\
(0.00)\end{array}$ & & \\
\hline Ln(Outsider Directors) MULTISEGMENT Dummy & & & & $\begin{array}{l}0.270^{\star * *} \\
(0.00)\end{array}$ \\
\hline Percentage of Outside Directors & $\begin{array}{l}0.102 \\
(0.24)\end{array}$ & $\begin{array}{l}0.298^{*} \\
(0.06)\end{array}$ & $\begin{array}{l}0.115 \\
(0.19)\end{array}$ & $\begin{array}{l}0.332^{* *} \\
(0.04)\end{array}$ \\
\hline Firm and Year Indicators & Yes & Yes & Yes & Yes \\
\hline Adjusted $\mathrm{R}^{2}$ & 0.746 & 0.748 & 0.745 & 0.747 \\
\hline
\end{tabular}


Table III

Cross-Sectional Regressions of Change in Tobin's Q on Board Changes over the Depression period

This table presents the result of the cross-sectional regressions of change in Tobin's Q on firm characteristics over the Depression years, 19301938 period. The change variables are calculated as changes for each firm from 1930 to 1938 . The other firm characteristics are at their median values over the years 1930-1938. Two-sided p-values are reported in parentheses. The regressions have an unreported intercept term. ${ }^{* * *},{ }^{* *},{ }^{*}$ represent significance at 1,5 , and $10 \%$, respectively.

\begin{tabular}{|c|c|c|c|c|c|c|c|c|}
\hline Variable & $(1)$ & $(2)$ & (3) & $(4)$ & $(5)$ & (6) & $(7)$ & (8) \\
\hline & \multicolumn{2}{|c|}{$\underline{\text { Small Firms }}$} & \multicolumn{2}{|c|}{$\underline{\text { Single-segment Firms }}$} & \multicolumn{2}{|c|}{$\underline{\text { Large Firms }}$} & \multicolumn{2}{|c|}{ Multi-segment Firms } \\
\hline Change in Growth Options & $\begin{array}{l}0.108^{* * *} \\
(0.00)\end{array}$ & $\begin{array}{l}0.108^{\star \star *} \\
(0.00)\end{array}$ & $\begin{array}{l}0.111^{\star * *} \\
(0.00)\end{array}$ & $\begin{array}{l}0.110^{\star * *} \\
(0.00)\end{array}$ & $\begin{array}{l}0.256^{\star \star *} \\
(0.00)\end{array}$ & $\begin{array}{l}0.256^{* * *} \\
(0.00)\end{array}$ & $\begin{array}{l}0.137^{\star * *} \\
(0.00)\end{array}$ & $\begin{array}{l}0.139^{\star \star *} \\
(0.00)\end{array}$ \\
\hline Change in Operating Profit & $\begin{array}{l}0.000 \\
(0.93)\end{array}$ & $\begin{array}{l}0.000 \\
(0.93)\end{array}$ & $\begin{array}{l}0.000 \\
(0.96)\end{array}$ & $\begin{array}{l}0.000 \\
(0.96)\end{array}$ & $\begin{array}{l}-0.008 \\
(0.15)\end{array}$ & $\begin{array}{l}-0.008 \\
(0.17)\end{array}$ & $\begin{array}{l}-0.003 \\
(0.57)\end{array}$ & $\begin{array}{l}-0.003 \\
(0.59)\end{array}$ \\
\hline Volatility & $\begin{array}{l}0.001 \\
(0.92)\end{array}$ & $\begin{array}{l}0.002 \\
(0.85)\end{array}$ & $\begin{array}{l}0.006 \\
(0.70)\end{array}$ & $\begin{array}{l}0.007 \\
(0.64)\end{array}$ & $\begin{array}{l}0.002 \\
(0.75)\end{array}$ & $\begin{array}{l}-0.001 \\
(0.91)\end{array}$ & $\begin{array}{l}-0.006 \\
(0.31)\end{array}$ & $\begin{array}{l}-0.009 \\
(0.13)\end{array}$ \\
\hline Leverage & $\begin{array}{l}-0.208 \\
(0.57)\end{array}$ & $\begin{array}{l}-0.181 \\
(0.62)\end{array}$ & $\begin{array}{l}-0.275 \\
(0.48)\end{array}$ & $\begin{array}{l}-0.242 \\
(0.53)\end{array}$ & $\begin{array}{l}0.142 \\
(0.54)\end{array}$ & $\begin{array}{l}0.147 \\
(0.53)\end{array}$ & $\begin{array}{l}0.287 \\
(0.21)\end{array}$ & $\begin{array}{l}0.304 \\
(0.18)\end{array}$ \\
\hline Tangibility & $\begin{array}{l}0.414^{*} \\
(0.07)\end{array}$ & $\begin{array}{l}0.433^{*} \\
(0.06)\end{array}$ & $\begin{array}{l}0.434^{*} \\
(0.07)\end{array}$ & $\begin{array}{l}0.463^{*} \\
(0.05)\end{array}$ & $\begin{array}{l}-0.127 \\
(0.40)\end{array}$ & $\begin{array}{l}-0.122 \\
(0.42)\end{array}$ & $\begin{array}{l}-0.189 \\
(0.24)\end{array}$ & $\begin{array}{l}-0.196 \\
(0.22)\end{array}$ \\
\hline Liquidity & $\begin{array}{l}0.069 \\
(0.94)\end{array}$ & $\begin{array}{l}0.133 \\
(0.89)\end{array}$ & $\begin{array}{l}0.098 \\
(0.92)\end{array}$ & $\begin{array}{l}0.164 \\
(0.87)\end{array}$ & $\begin{array}{l}-0.914 \\
(0.27)\end{array}$ & $\begin{array}{l}-1.017 \\
(0.23)\end{array}$ & $\begin{array}{l}-1.628^{*} \\
(0.06)\end{array}$ & $\begin{array}{l}-1.813^{\star *} \\
(0.04)\end{array}$ \\
\hline Change in Board Size $<0$ & $\begin{array}{l}0.179^{*} \\
(0.07)\end{array}$ & & $\begin{array}{l}0.221^{\star *} \\
(0.04)\end{array}$ & & & & & \\
\hline Change in No. of Outside Directors $<0$ & & $\begin{array}{l}0.165^{\star} \\
(0.09)\end{array}$ & & $\begin{array}{l}0.198^{*} \\
(0.06)\end{array}$ & & & & \\
\hline Change in Board Size $>0$ & & & & & $\begin{array}{l}0.128^{* *} \\
(0.04)\end{array}$ & & $\begin{array}{l}0.139^{* *} \\
(0.03)\end{array}$ & \\
\hline Change in No. of Outside Directors $>0$ & & & & & & $\begin{array}{l}0.115^{\star} \\
(0.06)\end{array}$ & & $\begin{array}{l}0.160^{\star *} \\
(0.01)\end{array}$ \\
\hline $\begin{array}{l}\text { Firm and Year Indicators } \\
\text { Adjusted } \mathrm{R}^{2}\end{array}$ & $\begin{array}{l}\text { Yes } \\
0.148\end{array}$ & $\begin{array}{l}\text { Yes } \\
0.147\end{array}$ & $\begin{array}{l}\text { Yes } \\
0.152\end{array}$ & $\begin{array}{l}\text { Yes } \\
0.149\end{array}$ & $\begin{array}{l}\text { Yes } \\
0.386\end{array}$ & $\begin{array}{l}\text { Yes } \\
0.380\end{array}$ & $\begin{array}{l}\text { Yes } \\
0.306\end{array}$ & $\begin{array}{l}\text { Yes } \\
0.317\end{array}$ \\
\hline
\end{tabular}




\section{Table IV}

\section{Regression of Debt Usage on Firm Characteristics for the Depression Years}

This table reports the result of the firm fixed effects regression of debt usage on firm characteristics for the Depression years, 1930-1938. Columns (1) and (3) use board size as the governance variable, while columns (2) and (4) use In(outside directors). The regressions have an unreported intercept term. Twosided $p$-values are reported in the parentheses. ${ }^{* * *},{ }^{* *},{ }^{*}$ represent significance at 1,5 , and $10 \%$, respectively.

\begin{tabular}{|c|c|c|c|c|}
\hline Variable & (1) & (2) & (3) & (4) \\
\hline Growth Options & $\begin{array}{l}-0.001 \\
(0.58)\end{array}$ & $\begin{array}{l}-0.001 \\
(0.63)\end{array}$ & $\begin{array}{l}-0.002 \\
(0.50)\end{array}$ & $\begin{array}{l}-0.001 \\
(0.61)\end{array}$ \\
\hline Operating Profit & $\begin{array}{l}0.016 \\
(0.36)\end{array}$ & $\begin{array}{l}0.018 \\
(0.31)\end{array}$ & $\begin{array}{l}0.018 \\
(0.31)\end{array}$ & $\begin{array}{l}0.018 \\
(0.30)\end{array}$ \\
\hline Volatility & $\begin{array}{l}0.000 \\
(0.97)\end{array}$ & $\begin{array}{l}-0.000 \\
(1.00)\end{array}$ & $\begin{array}{l}0.000 \\
(1.00)\end{array}$ & $\begin{array}{l}-0.000 \\
(0.96)\end{array}$ \\
\hline Leverage & $\begin{array}{l}-0.596^{* * *} \\
(0.00)\end{array}$ & $\begin{array}{l}-0.597^{\star * *} \\
(0.00)\end{array}$ & $\begin{array}{l}-0.597^{* * *} \\
(0.00)\end{array}$ & $\begin{array}{l}-0.600^{* * *} \\
(0.00)\end{array}$ \\
\hline Tangibility & $\begin{array}{l}0.085^{\star \star *} \\
(0.00)\end{array}$ & $\begin{array}{l}0.084^{* * *} \\
(0.00)\end{array}$ & $\begin{array}{l}0.085^{\star \star \star} \\
(0.00)\end{array}$ & $\begin{array}{l}0.084^{* \star *} \\
(0.00)\end{array}$ \\
\hline Investment & $\begin{array}{l}0.106^{* * *} \\
(0.00)\end{array}$ & $\begin{array}{l}0.107^{* * *} \\
(0.00)\end{array}$ & $\begin{array}{l}0.106^{* * *} \\
(0.00)\end{array}$ & $\begin{array}{l}0.106^{* * *} \\
(0.00)\end{array}$ \\
\hline Firm Size & $\begin{array}{l}-0.004 \\
(0.49)\end{array}$ & $\begin{array}{l}-0.004 \\
(0.54)\end{array}$ & $\begin{array}{l}-0.005 \\
(0.40)\end{array}$ & $\begin{array}{l}-0.005 \\
(0.44)\end{array}$ \\
\hline LARGE Dummy & $\begin{array}{l}0.083^{* *} \\
(0.03)\end{array}$ & $\begin{array}{l}0.018 \\
(0.30)\end{array}$ & & \\
\hline MULTISEGMENT Dummy & & & $\begin{array}{l}0.074 \\
(0.28)\end{array}$ & $\begin{array}{l}0.016 \\
(0.77)\end{array}$ \\
\hline Liquidity & $\begin{array}{l}-0.074^{* * *} \\
(0.00)\end{array}$ & $\begin{array}{l}-0.073^{* * *} \\
(0.01)\end{array}$ & $\begin{array}{l}-0.077^{* * *} \\
(0.00)\end{array}$ & $\begin{array}{l}-0.077^{* * *} \\
(0.00)\end{array}$ \\
\hline Board Size & $\begin{array}{l}0.044^{* * *} \\
(0.00)\end{array}$ & & $\begin{array}{l}0.044^{* * *} \\
(0.00)\end{array}$ & \\
\hline Board Size*LARGE Dummy & $\begin{array}{l}-0.035^{\star *} \\
(0.02)\end{array}$ & & & \\
\hline Board Size* MULTISEGMENT Dummy & & & $\begin{array}{l}-0.041^{* *} \\
(0.04)\end{array}$ & \\
\hline Ln(Outside Directors) & & $\begin{array}{l}0.035^{* * *} \\
(0.00)\end{array}$ & & $\begin{array}{l}0.037^{* * *} \\
(0.00)\end{array}$ \\
\hline Ln(Outside Directors) ${ }^{*}$ LARGE Dummy & & $\begin{array}{l}-0.019 \\
(0.10)^{*}\end{array}$ & & \\
\hline Ln(Outside Directors)* MULTISEGMENT Dummy & & & & $\begin{array}{l}-0.026^{* *} \\
(0.02)\end{array}$ \\
\hline Percentage of Outside Directors & $\begin{array}{l}-0.005 \\
(0.72)\end{array}$ & $\begin{array}{l}-0.074^{* * *} \\
(0.00)\end{array}$ & $\begin{array}{l}-0.007 \\
(0.60)\end{array}$ & $\begin{array}{l}-0.073^{\star * *} \\
(0.00)\end{array}$ \\
\hline $\begin{array}{l}\text { Firm and Year Indicators } \\
\text { Adiusted } B^{2}\end{array}$ & $\begin{array}{l}\text { Yes } \\
0.310\end{array}$ & $\begin{array}{l}\text { Yes } \\
0.309\end{array}$ & $\begin{array}{l}\text { Yes } \\
0.314\end{array}$ & $\begin{array}{l}\text { Yes } \\
0.314\end{array}$ \\
\hline
\end{tabular}


Table V

Cross-Sectional Regression of Change in Debt Usage on Board Changes over the Depression period

This table presents the result of the cross-sectional regressions of change in debt usage on firm characteristics over the Depression years, 19301938. The change variables are calculated as changes for each firm from 1930 to 1938. The other firm characteristics are at their median values over the years 1930-1938. Two sided $p$-values are reported in parentheses. The regressions have an unreported intercept term. ${ }^{* * *},{ }^{* *},{ }^{*}$ represent significance at 1,5 , and $10 \%$, respectively.

\begin{tabular}{|c|c|c|c|c|c|c|c|c|}
\hline Variable & $(1)$ & $(2)$ & (3) & (4) & (5) & (6) & $(7)$ & (8) \\
\hline & \multicolumn{2}{|c|}{$\underline{\text { Small Firms }}$} & \multicolumn{2}{|c|}{$\underline{\text { Single-segment Firms }}$} & \multicolumn{2}{|c|}{$\underline{\text { Large Firms }}$} & \multicolumn{2}{|c|}{ Multi-segment Firms } \\
\hline Change in Growth Options & $\begin{array}{l}-0.000 \\
(0.96)\end{array}$ & $\begin{array}{l}-0.000 \\
(0.99)\end{array}$ & $\begin{array}{l}0.000 \\
(0.57)\end{array}$ & $\begin{array}{l}0.000 \\
(0.54)\end{array}$ & $\begin{array}{l}-0.007 \\
(0.22)\end{array}$ & $\begin{array}{l}-0.008 \\
(0.22)\end{array}$ & $\begin{array}{l}-0.005^{\star \star} \\
(0.02)\end{array}$ & $\begin{array}{l}-0.005^{\star *} \\
(0.02)\end{array}$ \\
\hline Change in Operating Profit & $\begin{array}{l}-0.000 \\
(0.71)\end{array}$ & $\begin{array}{l}-0.000 \\
(0.71)\end{array}$ & $\begin{array}{l}-0.000 \\
(0.78)\end{array}$ & $\begin{array}{l}-0.000 \\
(0.78)\end{array}$ & $\begin{array}{l}0.000 \\
(0.74)\end{array}$ & $\begin{array}{l}0.000 \\
(0.73)\end{array}$ & $\begin{array}{l}0.000 \\
(0.77)\end{array}$ & $\begin{array}{l}0.000 \\
(0.78)\end{array}$ \\
\hline Volatility & $\begin{array}{l}0.002 \\
(0.12)\end{array}$ & $\begin{array}{l}0.002 \\
(0.15)\end{array}$ & $\begin{array}{l}0.002 \\
(0.21)\end{array}$ & $\begin{array}{l}0.002 \\
(0.31)\end{array}$ & $\begin{array}{l}-0.002 \\
(0.50)\end{array}$ & $\begin{array}{l}-0.002 \\
(0.55)\end{array}$ & $\begin{array}{l}0.000 \\
(0.80)\end{array}$ & $\begin{array}{l}0.000 \\
(0.84)\end{array}$ \\
\hline Leverage & $\begin{array}{l}-0.156^{\star \star \star} \\
(0.00)\end{array}$ & $\begin{array}{l}-0.157^{\star \star \star} \\
(0.00)\end{array}$ & $\begin{array}{l}-0.151^{\star \star \star} \\
(0.00)\end{array}$ & $\begin{array}{l}-0.152^{\star \star \star} \\
(0.00)\end{array}$ & $\begin{array}{l}-0.123 \\
(0.19)\end{array}$ & $\begin{array}{l}-0.116 \\
(0.22)\end{array}$ & $\begin{array}{l}-0.108 \\
(0.13)\end{array}$ & $\begin{array}{l}-0.107 \\
(0.13)\end{array}$ \\
\hline Tangibility & $\begin{array}{l}0.069^{* *} \\
(0.01)\end{array}$ & $\begin{array}{l}0.059^{* *} \\
(0.04)\end{array}$ & $\begin{array}{l}0.055^{\star} \\
(0.06)\end{array}$ & $\begin{array}{l}0.046 \\
(0.13)\end{array}$ & $\begin{array}{l}-0.031 \\
(0.62)\end{array}$ & $\begin{array}{l}-0.029 \\
(0.65)\end{array}$ & $\begin{array}{l}0.039 \\
(0.46)\end{array}$ & $\begin{array}{l}0.040 \\
(0.45)\end{array}$ \\
\hline Investment & $\begin{array}{l}0.144^{* * *} \\
(0.00)\end{array}$ & $\begin{array}{l}0.144^{\star * \star} \\
(0.00)\end{array}$ & $\begin{array}{l}0.150^{\star * *} \\
(0.00)\end{array}$ & $\begin{array}{l}0.149^{* * *} \\
(0.00)\end{array}$ & $\begin{array}{l}0.254^{* * *} \\
(0.00)\end{array}$ & $\begin{array}{l}0.252^{* * *} \\
(0.00)\end{array}$ & $\begin{array}{l}0.231^{* * *} \\
(0.00)\end{array}$ & $\begin{array}{l}0.235^{\star * *} \\
(0.00)\end{array}$ \\
\hline Firm Size & $\begin{array}{l}-0.009 \\
(0.16)\end{array}$ & $\begin{array}{l}-0.009 \\
(0.18)\end{array}$ & $\begin{array}{l}-0.002 \\
(0.81)\end{array}$ & $\begin{array}{l}-0.001 \\
(0.93)\end{array}$ & $\begin{array}{l}-0.012 \\
(0.41)\end{array}$ & $\begin{array}{l}-0.012 \\
(0.40)\end{array}$ & $\begin{array}{l}0.000 \\
(1.00)\end{array}$ & $\begin{array}{l}-0.000 \\
(0.98)\end{array}$ \\
\hline Liquidity & $\begin{array}{l}-0.131 \\
(0.24)\end{array}$ & $\begin{array}{l}-0.140 \\
(0.21)\end{array}$ & $\begin{array}{l}-0.096 \\
(0.42)\end{array}$ & $\begin{array}{l}-0.096 \\
(0.42)\end{array}$ & $\begin{array}{l}-0.485 \\
(0.13)\end{array}$ & $\begin{array}{l}-0.470 \\
(0.14)\end{array}$ & $\begin{array}{l}-0.361 \\
(0.17)\end{array}$ & $\begin{array}{l}-0.361 \\
(0.17)\end{array}$ \\
\hline Change in Board Size $<0$ & $\begin{array}{l}-0.029^{* *} \\
(0.01)\end{array}$ & & $\begin{array}{l}-0.028^{* *} \\
(0.02)\end{array}$ & & & & & \\
\hline Change in No. of Outside Directors $<0$ & & $\begin{array}{l}-0.024^{* *} \\
(0.04)\end{array}$ & & $\begin{array}{l}-0.023^{*} \\
(0.07)\end{array}$ & & & & \\
\hline Change in Board Size $>0$ & & & & & $\begin{array}{l}0.017 \\
(0.54)\end{array}$ & & $\begin{array}{l}-0.005 \\
(0.83)\end{array}$ & \\
\hline Change in No. of Outside Directors $>0$ & & & & & & $\begin{array}{l}0.011 \\
(0.65)\end{array}$ & & $\begin{array}{l}0.002 \\
(0.93)\end{array}$ \\
\hline $\begin{array}{l}\text { Firm and Year Indicators } \\
\text { Adjusted } \mathrm{R}^{2}\end{array}$ & $\begin{array}{l}\text { Yes } \\
0.145\end{array}$ & $\begin{array}{l}\text { Yes } \\
0.139\end{array}$ & $\begin{array}{l}\text { Yes } \\
0.132\end{array}$ & $\begin{array}{l}\text { Yes } \\
0.126\end{array}$ & $\begin{array}{l}\text { Yes } \\
0.194\end{array}$ & $\begin{array}{l}\text { Yes } \\
0.192\end{array}$ & $\begin{array}{l}\text { Yes } \\
0.244\end{array}$ & $\begin{array}{l}\text { Yes } \\
0.244\end{array}$ \\
\hline
\end{tabular}




\section{Table VI}

\section{Regression of Investment on Firm Characteristics for the Depression years}

This table presents the result of the firm fixed effects regression of investment on firm characteristics for the Depression years, 1930-1938. Columns (1) and (3) use board size as the governance variable, while columns (2) and (4) use In(outside directors). Two-sided p-values are reported in the parentheses. The regressions have an unreported intercept term. ${ }^{* * *},{ }^{* *},{ }^{*}$ represent significance at 1,5 , and $10 \%$, respectively.

\begin{tabular}{|c|c|c|c|c|}
\hline Variable & (1) & $(2)$ & (3) & (4) \\
\hline Growth Options & $\begin{array}{l}0.012^{\star * *} \\
(0.00)\end{array}$ & $\begin{array}{l}0.013^{\star \star *} \\
(0.00)\end{array}$ & $\begin{array}{l}0.012^{\star \star \star} \\
(0.00)\end{array}$ & $\begin{array}{l}0.013^{* \star *} \\
(0.00)\end{array}$ \\
\hline Operating Profit & $\begin{array}{l}0.006 \\
(0.84)\end{array}$ & $\begin{array}{l}0.004 \\
(0.91)\end{array}$ & $\begin{array}{l}0.004 \\
(0.90)\end{array}$ & $\begin{array}{l}0.001 \\
(0.98)\end{array}$ \\
\hline Volatility & $\begin{array}{l}-0.000 \\
(0.88)\end{array}$ & $\begin{array}{l}-0.000 \\
(0.87)\end{array}$ & $\begin{array}{l}-0.000 \\
(0.90)\end{array}$ & $\begin{array}{l}-0.000 \\
(0.88)\end{array}$ \\
\hline Tangibility & $\begin{array}{l}-0.477^{\star * *} \\
(0.00)\end{array}$ & $\begin{array}{l}-0.477^{\star \star \star} \\
(0.00)\end{array}$ & $\begin{array}{l}-0.479^{\star \star \star} \\
(0.00)\end{array}$ & $\begin{array}{l}-0.480^{\star \star \star} \\
(0.00)\end{array}$ \\
\hline Firm Size & $\begin{array}{l}-0.126^{\star * *} \\
(0.00)\end{array}$ & $\begin{array}{l}-0.131^{* * *} \\
(0.00)\end{array}$ & $\begin{array}{l}-0.129^{* * *} \\
(0.00)\end{array}$ & $\begin{array}{l}-0.133^{* * *} \\
(0.00)\end{array}$ \\
\hline LARGE Dummy & $\begin{array}{l}0.115^{*} \\
(0.08)\end{array}$ & $\begin{array}{l}0.022 \\
(0.46)\end{array}$ & & \\
\hline MULTISEGMENT Dummy & & & $\begin{array}{l}0.184 \\
(0.13)\end{array}$ & $\begin{array}{l}0.052 \\
(0.59)\end{array}$ \\
\hline Board Size & $\begin{array}{l}0.075^{\star \star *} \\
(0.00)\end{array}$ & & $\begin{array}{l}0.084^{* * *} \\
(0.00)\end{array}$ & \\
\hline Board Size* LARGE Dummy & $\begin{array}{l}-0.055^{\star \star} \\
(0.04)\end{array}$ & & & \\
\hline Board Size* MULTISEGMENT Dummy & & & $\begin{array}{l}-0.078^{* *} \\
(0.03)\end{array}$ & \\
\hline Ln(Outside Directors) & & $\begin{array}{l}0.057^{* * *} \\
(0.00)\end{array}$ & & $\begin{array}{l}0.061^{* * *} \\
(0.00)\end{array}$ \\
\hline Ln(Outside Directors)* LARGE Dummy & & $\begin{array}{l}-0.027^{*} \\
(0.10)\end{array}$ & & \\
\hline Ln(Outside Directors)* MULTISEGMENT Dummy & & & & $\begin{array}{l}-0.035^{*} \\
(0.07)\end{array}$ \\
\hline Percentage of Outside Directors & $\begin{array}{l}0.020 \\
(0.40)\end{array}$ & $\begin{array}{l}-0.076^{*} \\
(0.08)\end{array}$ & $\begin{array}{l}0.017 \\
(0.48)\end{array}$ & $\begin{array}{l}-0.078^{*} \\
(0.07)\end{array}$ \\
\hline $\begin{array}{l}\text { Firm and Year Indicators } \\
\text { Adjusted } \mathrm{R}^{2}\end{array}$ & $\begin{array}{l}\text { Yes } \\
0.219\end{array}$ & $\begin{array}{l}\text { Yes } \\
0.215\end{array}$ & $\begin{array}{l}\text { Yes } \\
0.219\end{array}$ & $\begin{array}{l}\text { Yes } \\
0.215\end{array}$ \\
\hline
\end{tabular}




\section{Table VII}

\section{Cross-Sectional Regressions of Change in Investment on Board Changes over the Depression period}

This table presents the result of the cross-sectional regressions of change in investment on firm characteristics over the Depression years, 19301938 period. The change variables are calculated as changes for each firm from 1930 to 1938. The other firm characteristics are at their median values over the years 1930-1938. Two-sided p-values are reported in parentheses. The regressions have an unreported intercept term. ${ }^{* * *},{ }^{* *},{ }^{*}$ represent significance at 1,5 , and $10 \%$, respectively.

\begin{tabular}{|c|c|c|c|c|c|c|c|c|}
\hline Variable & $(1)$ & $(2)$ & (3) & (4) & $(5)$ & (6) & $(7)$ & (8) \\
\hline & \multicolumn{2}{|c|}{$\underline{\text { Small Firms }}$} & \multicolumn{2}{|c|}{$\underline{\text { Single-segment Firms }}$} & \multicolumn{2}{|c|}{$\underline{\text { Large Firms }}$} & \multicolumn{2}{|c|}{$\underline{\text { Multi-segment Firms }}$} \\
\hline Change in Growth Options & $\begin{array}{l}-0.001 \\
(0.32)\end{array}$ & $\begin{array}{l}-0.001 \\
(0.39)\end{array}$ & $\begin{array}{l}-0.001 \\
(0.30)\end{array}$ & $\begin{array}{l}-0.001 \\
(0.37)\end{array}$ & $\begin{array}{l}-0.012 \\
(0.27)\end{array}$ & $\begin{array}{l}-0.011 \\
(0.28)\end{array}$ & $\begin{array}{l}-0.003 \\
(0.41)\end{array}$ & $\begin{array}{l}-0.003 \\
(0.40)\end{array}$ \\
\hline Change in Operating Profit & $\begin{array}{l}0.000 \\
(0.99)\end{array}$ & $\begin{array}{l}0.000 \\
(0.99)\end{array}$ & $\begin{array}{l}0.000 \\
(0.92)\end{array}$ & $\begin{array}{l}0.000 \\
(0.92)\end{array}$ & $\begin{array}{l}0.000 \\
(0.34)\end{array}$ & $\begin{array}{l}0.000 \\
(0.31)\end{array}$ & $\begin{array}{l}0.000 \\
(0.45)\end{array}$ & $\begin{array}{l}0.000 \\
(0.42)\end{array}$ \\
\hline Volatility & $\begin{array}{l}-0.001 \\
(0.71)\end{array}$ & $\begin{array}{l}-0.002 \\
(0.62)\end{array}$ & $\begin{array}{l}-0.002 \\
(0.54)\end{array}$ & $\begin{array}{l}-0.003 \\
(0.39)\end{array}$ & $\begin{array}{l}0.008^{*} \\
(0.09)\end{array}$ & $\begin{array}{l}0.008 \\
(0.11)\end{array}$ & $\begin{array}{l}0.006 \\
(0.14)\end{array}$ & $\begin{array}{l}0.005 \\
(0.16)\end{array}$ \\
\hline Tangibility & $\begin{array}{l}-0.287^{\star * *} \\
(0.00)\end{array}$ & $\begin{array}{l}-0.309^{\star * *} \\
(0.00)\end{array}$ & $\begin{array}{l}-0.289^{\star \star *} \\
(0.00)\end{array}$ & $\begin{array}{l}-0.312^{\star \star *} \\
(0.00)\end{array}$ & $\begin{array}{l}-0.311^{\star * *} \\
(0.00)\end{array}$ & $\begin{array}{l}-0.332^{* * *} \\
(0.00)\end{array}$ & $\begin{array}{l}-0.307^{* * *} \\
(0.00)\end{array}$ & $\begin{array}{l}-0.324^{\star * *} \\
(0.00)\end{array}$ \\
\hline Firm Size & $\begin{array}{l}0.026^{*} \\
(0.07)\end{array}$ & $\begin{array}{l}0.028^{*} \\
(0.05)\end{array}$ & $\begin{array}{l}0.038^{* *} \\
(0.01)\end{array}$ & $\begin{array}{l}0.040^{\star * *} \\
(0.01)\end{array}$ & $\begin{array}{l}-0.032 \\
(0.20)\end{array}$ & $\begin{array}{l}-0.029 \\
(0.25)\end{array}$ & $\begin{array}{l}0.014 \\
(0.50)\end{array}$ & $\begin{array}{l}0.019 \\
(0.38)\end{array}$ \\
\hline Change in Board Size $<0$ & $\begin{array}{l}-0.048^{* *} \\
(0.05)\end{array}$ & & $\begin{array}{l}-0.044^{*} \\
(0.09)\end{array}$ & & & & & \\
\hline Change in No. of Outside Directors $<0$ & & $\begin{array}{l}-0.059^{* *} \\
(0.02)\end{array}$ & & $\begin{array}{l}-0.060^{* *} \\
(0.02)\end{array}$ & & & & \\
\hline Change in Board Size $>0$ & & & & & $\begin{array}{l}-0.113^{\star *} \\
(0.02)\end{array}$ & & $\begin{array}{l}-0.094^{* *} \\
(0.04)\end{array}$ & \\
\hline Change in No. of Outside Directors $>0$ & & & & & & $\begin{array}{l}-0.100^{* *} \\
(0.02)\end{array}$ & & $\begin{array}{l}-0.080^{*} \\
(0.05)\end{array}$ \\
\hline $\begin{array}{l}\text { Firm and Year Indicators } \\
\text { Adjusted } \mathrm{R}^{2}\end{array}$ & $\begin{array}{l}\text { Yes } \\
0.093\end{array}$ & $\begin{array}{l}\text { Yes } \\
0.098\end{array}$ & $\begin{array}{l}\text { Yes } \\
0.098\end{array}$ & $\begin{array}{l}\text { Yes } \\
0.105\end{array}$ & $\begin{array}{l}\text { Yes } \\
0.174\end{array}$ & $\begin{array}{l}\text { Yes } \\
0.173\end{array}$ & $\begin{array}{l}\text { Yes } \\
0.127\end{array}$ & $\begin{array}{l}\text { Yes } \\
0.122\end{array}$ \\
\hline
\end{tabular}




\section{Table VIII}

\section{Regression of Change in Tobin's $Q$ on Firm Characteristics for the Depression years}

This table presents the result of the firm fixed effects regression of change in Tobin's $Q$ on firm characteristics for the Depression years, 1930-1938. Two-sided p-values are reported in parentheses. The regressions have an unreported intercept term. ${ }^{* * *},{ }^{* *},{ }^{*}$ represent significance at 1,5 , and $10 \%$, respectively.

\begin{tabular}{|c|c|c|c|c|c|c|}
\hline Variable & (1) & (2) & (3) & (4) & (5) & (6) \\
\hline Change in Growth Options & $\begin{array}{l}0.640^{* * *} \\
(0.00)\end{array}$ & $\begin{array}{l}0.640^{\star * *} \\
(0.00)\end{array}$ & $\begin{array}{l}0.640^{\star * *} \\
(0.00)\end{array}$ & $\begin{array}{l}0.640^{* * *} \\
(0.00)\end{array}$ & $\begin{array}{l}0.640^{\star * *} \\
(0.00)\end{array}$ & $\begin{array}{l}0.640^{* * *} \\
(0.00)\end{array}$ \\
\hline Change in Operating Profit & $\begin{array}{l}0.043 \\
(0.48)\end{array}$ & $\begin{array}{l}0.042 \\
(0.49)\end{array}$ & $\begin{array}{l}0.043 \\
(0.48)\end{array}$ & $\begin{array}{l}0.042 \\
(0.49)\end{array}$ & $\begin{array}{l}0.043 \\
(0.47)\end{array}$ & $\begin{array}{l}0.042 \\
(0.49)\end{array}$ \\
\hline Volatility & $\begin{array}{l}-0.001^{* *} \\
(0.05)\end{array}$ & $\begin{array}{l}-0.001^{*} \\
(0.05)\end{array}$ & $\begin{array}{l}-0.001^{* *} \\
(0.05)\end{array}$ & $\begin{array}{l}-0.001^{*} \\
(0.05)\end{array}$ & $\begin{array}{l}-0.001^{* *} \\
(0.05)\end{array}$ & $\begin{array}{l}-0.001^{* *} \\
(0.05)\end{array}$ \\
\hline Leverage & $\begin{array}{l}-0.031 \\
(0.71)\end{array}$ & $\begin{array}{l}-0.032 \\
(0.71)\end{array}$ & $\begin{array}{l}-0.031 \\
(0.72)\end{array}$ & $\begin{array}{l}-0.031 \\
(0.71)\end{array}$ & $\begin{array}{l}-0.034 \\
(0.69)\end{array}$ & $\begin{array}{l}-0.033 \\
(0.69)\end{array}$ \\
\hline LARGE Dummy & $\begin{array}{l}0.016 \\
(0.58)\end{array}$ & & $\begin{array}{l}0.016 \\
(0.59)\end{array}$ & & $\begin{array}{l}0.021 \\
(0.49)\end{array}$ & \\
\hline MULTISEGMENT Dummy & & $\begin{array}{l}-0.245 \\
(0.24)\end{array}$ & & $\begin{array}{l}-0.244 \\
(0.25)\end{array}$ & & $\begin{array}{l}-0.246 \\
(0.24)\end{array}$ \\
\hline Tangibility & $\begin{array}{l}-0.129^{* *} \\
(0.03)\end{array}$ & $\begin{array}{l}-0.131^{* *} \\
(0.03)\end{array}$ & $\begin{array}{l}-0.129^{* *} \\
(0.03)\end{array}$ & $\begin{array}{l}-0.131^{* *} \\
(0.03)\end{array}$ & $\begin{array}{l}-0.129^{* *} \\
(0.03)\end{array}$ & $\begin{array}{l}-0.131^{* *} \\
(0.03)\end{array}$ \\
\hline Liquidity & $\begin{array}{l}-0.127 \\
(0.19)\end{array}$ & $\begin{array}{l}-0.130 \\
(0.19)\end{array}$ & $\begin{array}{l}-0.127 \\
(0.19)\end{array}$ & $\begin{array}{l}-0.130 \\
(0.19)\end{array}$ & $\begin{array}{l}-0.125 \\
(0.20)\end{array}$ & $\begin{array}{l}-0.128 \\
(0.19)\end{array}$ \\
\hline Debt Usage & $\begin{array}{l}-0.155^{\star *} \\
(0.05)\end{array}$ & $\begin{array}{l}-0.154^{*} \\
(0.05)\end{array}$ & $\begin{array}{l}-0.148^{\star} \\
(0.07)\end{array}$ & $\begin{array}{l}-0.153^{*} \\
(0.07)\end{array}$ & $\begin{array}{l}-0.153^{*} \\
(0.05)\end{array}$ & $\begin{array}{l}-0.153^{*} \\
(0.06)\end{array}$ \\
\hline Debt Usage *LARGE Dummy & & & $\begin{array}{l}-0.054 \\
(0.78)\end{array}$ & & & \\
\hline Debt Usage * MULTISEGMENT Dummy & & & & $\begin{array}{l}-0.008 \\
(0.96)\end{array}$ & & \\
\hline Investment & $\begin{array}{l}-0.071 \\
(0.11)\end{array}$ & $\begin{array}{l}-0.073^{*} \\
(0.10)\end{array}$ & $\begin{array}{l}-0.071 \\
(0.11)\end{array}$ & $\begin{array}{l}-0.073^{*} \\
(0.10)\end{array}$ & $\begin{array}{l}-0.090^{*} \\
(0.06)\end{array}$ & $\begin{array}{l}-0.093^{*} \\
(0.06)\end{array}$ \\
\hline Investment*LARGE Dummy & & & & & $\begin{array}{l}0.103 \\
(0.31)\end{array}$ & \\
\hline Investment* MULTISEGMENT Dummy & & & & & & $\begin{array}{l}0.088 \\
(0.36)\end{array}$ \\
\hline Firm and Year Indicators & Yes & Yes & Yes & Yes & Yes & Yes \\
\hline Adjusted $\mathrm{R}^{2}$ & 0.812 & 0.811 & 0.812 & 0.811 & 0.812 & 0.811 \\
\hline
\end{tabular}

